\title{
Seismic Vulnerability of RC Frame Building Using Gross and Cracked Section as per Indian Provisions
}

\author{
Kaushik Gondaliya $^{1 *}$, Jignesh Amin ${ }^{2}$, Sandip Vasanwala ${ }^{1}$, Atul Desai ${ }^{1}$ \\ ${ }^{I}$ Department of Civil Engineering, Sardar Vallabhbhai National Institute of Technology, \\ Surat-395007 (Gujarat), India \\ ${ }^{2}$ Department of Civil Engineering, Sardar Vallabhbhai Patel Institute of Technology, \\ Vasad-388306 (Gujarat), India
}

\begin{abstract}
Fragility analysis essential in the process of predicting the lateral deformation of the structure under earthquake force. Seismic assessment and vulnerability study of a 12-storey RC frame building is carried out. 12-storey RC frame is designed for Zone-V ( $\mathrm{Z}=0.36$ ) from IS 1893 using gross and cracked section property of frame elements. The designed buildings are analysed using non-linear static analysis to obtain the capacity curves. The bilinear idealisation of a pushover curve is carried out to get the response reduction factor of RC frame designed using gross and cracked section. The seismic hazard is defined using a 5\% response spectrum as specified in IS 1893 to assess the performance points. Fragility curves are developed for the RC frame building designed using gross and cracked section. The damage probability matrices (DPM) is formed at the performance points for different damage states of the design building. The results of the study express the damage grade of a 12-storey RC frame building for the seismic zones III, IV, \& V. The $\mathrm{RC}$ frame designed with a cracked section possesses almost 10 per cent less seismic vulnerability with comparison to the similar frame designed using gross section for seismic zone $\mathrm{V}$.
\end{abstract}

Keywords: Reinforce concrete, Cracked section, Response reduction factor, Fragility curve, Damage probability matrices.

\section{Introduction}

The fragility analysis is considered as a reliable method to predict the performance of structures in terms of probability of occurring particular damage state during the hazardous natural phenomenon. The past few earthquakes have created a substantial social and economic impact in India, such as Bhuj earthquake (2001) and the Indian Ocean earthquake (2004). The damage induced in the structure during seismic events depends on many factors like intensity of an earthquake, soil condition, frequency contents, lateral load resisting system. The building design methodology also plays a vital role in designing the lateral load resisting system. The conventional force-based seismic analysis and design of the building as per IS 1893 (Part-I):2002 recommended use of uncracked/gross section properties of frame elements. Whereas, the sixth revised edition of Indian seismic standard suggests the use of cracked section properties of frame elements for seismic analysis and design, i.e. 0.70Ig for columns and 0.35Ig for beams. The reduced moment of inertia of frame elements recommended by standards of some major country for seismic analysis is shown in Table [1], i.e. Standard code of Europe (Eurocode 8, 2005), India (IS 1893, 2016) and America (ACI, 2014).

Indian seismic code allows damage to the structures during major seismic events. The code allows the nonlinear behaviour of structures and cracking in a structure during cyclic vibration. Therefore, the properties of the members should require to be model according to consider the cracking of various elements during a significant seismic event. In the past, several efforts were made to evaluate the effects of the cracked section properties of the frame elements; on the seismic behaviour of structures. The use of the reduced moment of inertia for seismic design has considerable effects on the lateral strength, fundamental time-period, lateral stiffness, ductility, inter 
storey drift on the RC frame structure. (M. Ahmed et al. 2009; Mapari and Ghugal, 2018; Prajapati and Amin, 2019). Elnashai and Mwafy (2002) investigated relationships among structural characteristic of the overstrength factor and force reduction factor ( $\mathrm{R}$ factor) using nonlinear static as well as time history analysis. Alam et al. (2012) evaluated the $R$ factor and ductility $(\mu)$ of structures using nonlinear static analysis. The response modification factor $(\mathrm{R})$ of a structure is considerably affected by the cracked section properties of elements, structural analysis as well as a design consideration, fundamental time-period. (Mondal et al. 2013).

The poor performance of many structures, during past disastrous Bhuj earthquake, India in the year of 2001, exposed the seismic vulnerability of many structures during significant earthquakes. The fragility analysis began to widespread throughout the globe, owing to its simplified and adoptable analytical design methodology. It allows selection of the least vulnerable design structure which could resist the seismic loads. Halder and Paul (2016) evaluated the various damage state of a building using the capacity spectrum method. These various damage stages for both the global and local levels defined using the HAZUS guideline (HAZUS-MH MR5, 2003). Table [2] illustrates the various damage state description in detail (Bai et al. 2008), and Table [3] depicts the mean damage index adopted in the present study to define particular damage of the individual building. The capacity of a structure under the effect of earthquake loads can be evaluated using the capacity spectrum method (Barbat et al. 2008). Barbat (2008) proposed a formula shown below for various seismic performance limit damage state, which is defined using the yield and ultimate displacements obtained from the capacity curve, as per equation (1):

$$
\mathrm{S}_{\mathrm{d}, \mathrm{k}}=\left\{\begin{array}{lr}
0.7 D_{y} & \text { Slight } \\
D_{y} & \text { Moderate } \\
D_{y}+0.25\left(D_{u}-D_{y}\right) & \text { Severe } \\
D_{u} & \text { Complete }
\end{array}\right.
$$

In the past, many researchers have carried out several studies to determine the seismic vulnerability of RC frame buildings using a pre-defined uncertainty $(\beta)$ factor to derive fragility curves (Choudhury \& Kaushik, 2018; Surana, Singh, \& Lang, 2016). This methodology may not lead to the accurate estimation of failure probability for attaining a particular damage state in the structure.

Table 1 Reduce moment of inertia (I) comparison in various country provisions.

\begin{tabular}{|c|c|c|c|c|}
\hline $\begin{array}{l}\text { Structural } \\
\text { Member }\end{array}$ & $\begin{array}{l}\text { IS 1893: } \\
2002\end{array}$ & ACI $318-14$ & $\begin{array}{l}\text { IS } \\
\text { 1893: } 2016\end{array}$ & EURO-CODE 8 \\
\hline Beam & $\begin{array}{l}z \\
0 \\
0 \\
0 \\
0\end{array}$ & $0.30 \mathrm{I}_{\mathrm{g}}$ & $0.35 \mathrm{I}_{\mathrm{g}}$ & $0.50 \mathrm{I}_{\mathrm{g}}$ \\
\hline Column & $\begin{array}{l}\frac{3}{0} \\
0.0 \\
0\end{array}$ & $0.70 \mathrm{I}_{\mathrm{g}}$ & $0.70 I_{g}$ & $0.50 \mathrm{I}_{\mathrm{g}}$ \\
\hline
\end{tabular}

The present study is focused on the seismic performance evaluation of a 12-storey RC frame building located in an extreme seismic zone-V of IS 1893 (Part-I) having peak ground acceleration value of 0.36g using nonlinear static analysis. In the present study, the seismic vulnerability assessment of a 12-storey special moment resistant $\mathrm{RC}$ frame is carried out. The 12-storey RC frame is designed using the force-based method considering the uncracked/gross and effective/cracked section properties of beams and columns as per IS: 1893 (Part-I). Seismic vulnerability in terms of fragility curves for study RC frame is developed as per the HAZUS methodology using 
the different damage state. Uncertainty $(\beta)$ parameter of various damage state is derived using the capacity spectrum method.

Table 2 Description of the propose damage state.

\begin{tabular}{ll}
\hline Damage State & Description \\
\hline Slight & Structural repairs are not necessary. \\
Moderate & Repairable Structural damage has happened. \\
Severe & Significant structural damage occurred, still retrofitting possible. \\
Complete & Damage is noteworthy, which is impossible to retrofit. \\
\hline
\end{tabular}

\section{Modelling approach}

The numerical study is performed considering a 12-storey RC residential building frame member designed as per the IS 456 (2000) and IS 13920 (2016). The building is assumed to be located in seismic zone V as per IS 1893 (2016). The RC frame is considered to be a Special Moment Resisting Frame (SMRF) with the value of response reduction factor as 5, according to IS 1893:2016. The values of dead and live load are considered as 1 $\mathrm{kN} / \mathrm{m} 2$ and $3 \mathrm{kN} / \mathrm{m} 2$, according to IS 875 (1987) (Part- I) and IS 875 (1987) (Part-II), respectively. The dead load includes the self-weight of beams, columns, slabs, and walls. The slab thickness, internal wall thickness, and external wall thickness are selected as $150 \mathrm{~mm}, 115 \mathrm{~mm}$, and $230 \mathrm{~mm}$, respectively. A masonry wall is considered to be the non-structural element. The adopted unit weight of concrete and compressive strength is 25 $\mathrm{kN} / \mathrm{m} 3$ and $25 \mathrm{MPa}$, respectively. The yield strength of steel reinforcement considered for this study is 500 $\mathrm{MPa}$. The natural time-periods of these two RC frames designed for gross and cracked section properties are calculated considering 5\% damping, medium (Type II) soil, and zone V as per IS 1893:2016 (Part-I). Figure (1) illustrates the plan and elevation of an RC frame in detail. As seen from the figure, the RC frame is symmetrical in both the plan and the elevation view. Because of the symmetricity in plan and elevation of the RC frame, a two-directional building is modelled in a software tool SAP2000 (2020). The supports are considered to be fixed at the bottom.

For the design purpose, load combinations for the RC section are considered using IS 1893:2016 (Part-I), as shown below:

- $\quad[1.5($ Dead + Live $)]$

- $\quad[1.2($ Dead + Live \pm Earthquake $)]$

- $\quad[1.5($ Dead \pm Earthquake $)]$

- $[(0.9$ Dead $) \pm(1.5$ Earthquake $)]$ 
(a)

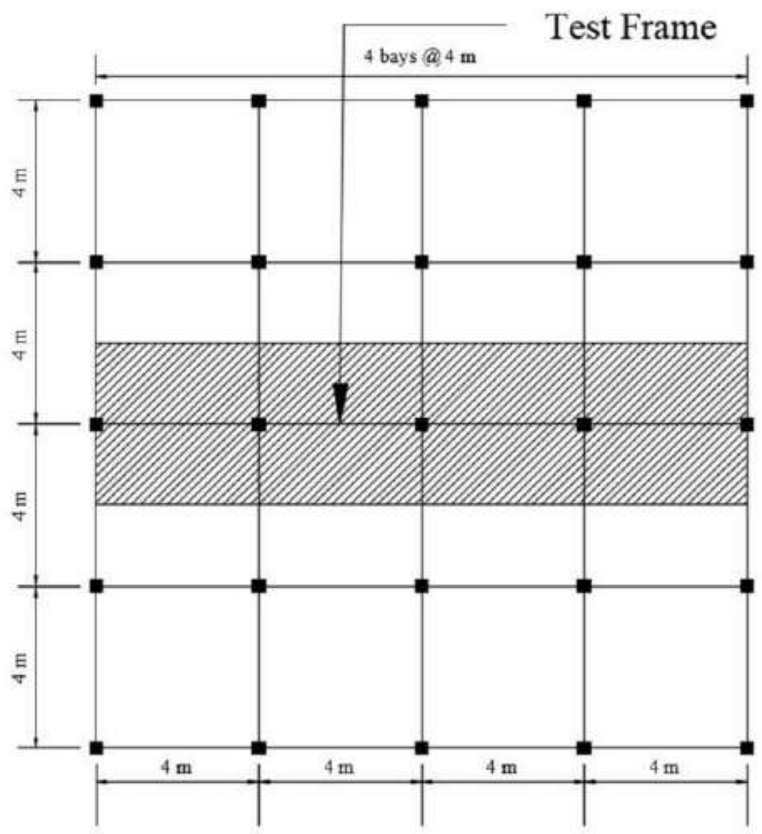

(b)

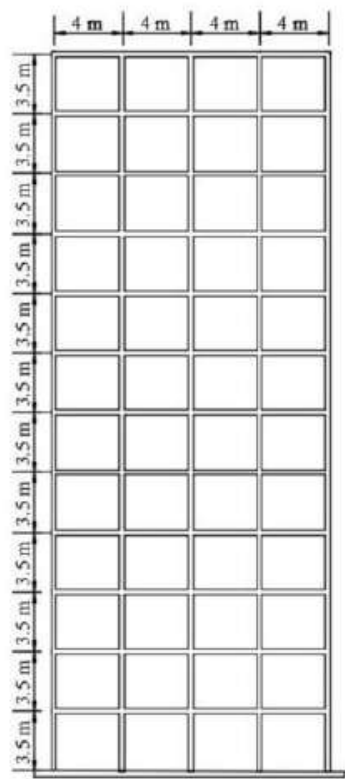

Figure 1 Details of a sample RC frame building: (a) plan view; (b) elevation view

Table 3 Reinforcement details of a 12-storey RC frame building.

\begin{tabular}{|c|c|c|c|c|c|}
\hline Floor & Member & $\begin{array}{l}\text { Width } \\
(\mathrm{mm})\end{array}$ & $\begin{array}{l}\text { Depth } \\
(\mathrm{mm})\end{array}$ & Cracked section & Gross section \\
\hline \multirow{3}{*}{$1-4$} & Beams & 300 & 550 & 4-16 $\Phi$ (top) + & 4-16 Ф (top) + \\
\hline & & & & 2-16 Ф (bottom) & 2-16 $\Phi$ (bottom) \\
\hline & Columns & 600 & 600 & $\begin{array}{l}12-25 \Phi \\
\text { (uniformly distributed) }\end{array}$ & $\begin{array}{l}4-25+4-20 \Phi \\
\text { (uniformly distributed) }\end{array}$ \\
\hline \multirow{3}{*}{$5-8$} & Beams & 250 & 500 & 4-16 Ф (top) + & 4-16 Ф (top) + \\
\hline & & & & 2-16 Ф (bottom) & $2-16 \Phi$ (bottom) \\
\hline & Columns & 525 & 525 & $\begin{array}{l}8-25 \Phi \\
\text { (uniformly distributed) }\end{array}$ & $\begin{array}{l}8-20 \Phi \\
\text { (uniformly distributed) }\end{array}$ \\
\hline \multirow{3}{*}{$9-12$} & Beams & 250 & 450 & $3-16 \Phi$ (top) + & 3-16 Ф (top) + \\
\hline & & & & 3-12 $\Phi$ (bottom) & 3-12 $\Phi$ (bottom) \\
\hline & Columns & 450 & 450 & $\begin{array}{l}8-20 \Phi \\
\text { (uniformly distributed) }\end{array}$ & $\begin{array}{l}\text { 8-16 } \Phi \\
\text { (uniformly distributed) }\end{array}$ \\
\hline
\end{tabular}

$\Phi$ represents the diameter of a rebar.

Table [4] shows the reinforcement bar data of RC frame elements designed as gross and cracked section properties, which confirms the strong column - weak beam behaviour of the building frame structure.

\section{Nonlinear static analysis}

The nonlinear static analysis is defined as the method in which, the monotonic lateral load is applied on the top of a structure incrementally to analyse the complete behaviour of a structure, from an elastic to the inelastic zone. It is also known as the pushover analysis. The total gravity load is applied to the top of a structure at the initial level. Equation (2) of IS: 1893 is used to define the lateral load patterns for the push loading. 


$$
\mathrm{Q}_{\mathrm{i}}=\frac{\mathrm{W}_{\mathrm{i}} \mathrm{h}_{\mathrm{i}}^{2}}{\sum_{\mathrm{i}=1}^{\mathrm{n}} \mathrm{W}_{\mathrm{i}} \mathrm{h}_{\mathrm{i}}^{2}} \mathrm{~V}_{\mathrm{d}}
$$

Where the seismic design force at floor i is denoted as Qi, the seismic weight at floor i is denoted as Wi, the height of floor i measured from the base is denoted as hi. It is essential for the materials utilized for beams and columns to consider the formation of plastic hinges, which could be modelled as non-linear frame elements with lumped plasticity. The Indian seismic codal provisions do not provide any details about the performance-based limit states. The location of the default plastic hinge is considered from the ASCE 41-13 (2014) at the global and local levels of structure.

Table 4 parameters of Response reduction factor for 12-storey RC frame building.

\begin{tabular}{lllllll}
\hline Section & $\mathrm{V}_{\mathrm{d}}(\mathrm{kN})$ & $\mathrm{V}_{\mathrm{u}}(\mathrm{kN})$ & $\Delta_{\mathrm{y}}(\mathrm{m})$ & $\Delta_{\mathrm{u}}(\mathrm{m})$ & $\boldsymbol{\mu}=\frac{\Delta \mathrm{u}}{\Delta \mathrm{y}}$ & $\Omega=\frac{\mathrm{Vu}}{\mathrm{Vd}}$ \\
\hline Gross & 426 & 1229 & 0.128 & 0.202 & 1.58 & 2.88 \\
Cracked & 426 & 1311 & 0.132 & 0.251 & 1.60 & 3.08 \\
\hline
\end{tabular}

The seismic load causes flexural deformations closer to the element boundaries, as the flexural hinges are specified to the member ends during the modelling process. The hinges P-M2-M3 are specified to the columns, whereas M3 hinges are specified to the beams. Moreover, the additional lateral displacement caused by the gravity load is considered during the nonlinear static analysis. This phenomenon is known as the P- $\Delta$ effect.

\section{Seismic hazard}

To calculate the seismic vulnerability, seismic demand is defined in terms of 5\% of the damped elastic response spectra. The Indian territory is divided into four seismic zones and three soil types. In the present study, the soil is considered to be the medium type of soil. Any other lateral load, including wind load, is not considered in this study. A 12-storey RC frame building is designed for the maximum earthquake force as per Indian seismic provisions (IS 1893, 2016). Design acceleration coefficient (Sa/g) normalized with the peak ground acceleration to the natural time-period ( $\mathrm{T}$ ) could be calculated by the following equation (3):

$$
\mathrm{S}_{\mathrm{a}} / \mathrm{g}=\left\{\begin{array}{lr}
1+1.5 T & T<0.10 s \\
2.5 & 0.10 s<T<0.40 s \\
\frac{1}{T} & 0.40 s<T<4.00 s \\
0.25 & T>4.00 s
\end{array}\right.
$$

Using the above equation, the response spectra scale is generated up to our design base shear $\left(\mathrm{V}_{\mathrm{d}}\right)$ for $5 \%$ critical damping. This response spectra are used as the demand spectra in acceleration-displacement response spectra (ADRS) format to derive the performance point at a specific seismic zone. Table [5] shows the calculations for peak ground acceleration, horizontal coefficient, and base shear for the three sets of seismic zones.

\section{Assessment of R factor}

The response reduction factor could differ in the cracked section due to the higher demand for designed RC members. The $\mathrm{R}$ factor is a function of several limits for the structural arrangements suggested by ATC-19 (1995) as defined in the following equation (4): 


$$
\mathrm{R}=\mathrm{R}_{\mathrm{S}} \times \mathrm{R}_{\mu} \times \mathrm{R}_{\mathrm{R}}
$$

Where RS is the over-strength factor, $\mathrm{R} \mu$ is the ductility factor, and RR is the redundancy. The bilinear approximation of a pushover curve to obtain the parameters is illustrated in Figure (2). The over-strength factor is an amount of fundamental strength in the structure, which could be evaluated by dividing the ultimate base shear $\left(\mathrm{V}_{\mathrm{u}}\right)$ by the design base shear $\left(\mathrm{V}_{\mathrm{d}}\right)$. The over-strength factor depends on the safety boundaries stated, as depicted in equation (5):

$$
\mathrm{R}_{\mathrm{S}}=\frac{V_{u}}{V_{d}}
$$

The ductility factor $(\mathrm{R} \mu)$ is the amount of total non-linear response of the structure to its plastic deformation capacity. As per ATC-19 (1995 cited Miranda and Bertero 1994) have performed the research on a relationship of $\mathrm{R} \mu-\mu-\mathrm{T}$ for alluvium soil sites. With reference to their study, the ductility factors are derived using the following equation (6):

$$
\mathrm{R}_{\mu}=\frac{\mu-1}{\Phi}+1
$$

Where $\Phi$ alluvium soil property is $1+\frac{1}{12 T-\mu T}-\frac{2}{5 T} e^{-2(\ln (T)-0.2)^{2}}$. Furthermore, $\mathrm{T}$ is a predominant period of the ground motion. The ductility capacity $(\mu)$ derived from the bi-linearization of pushover graphs for the deformation boundaries equivalent to the particular performance level was failed. As per the configuration of this study, the RR value is chosen as 1. Table [6-7] summarize the seismic assessment, Response reduction factor and its parameters of the 12-storey RC frame building design using gross and cracked section properties.

Table 5 12-storey RC frame building calculation of Response reduction factor.

\begin{tabular}{lllll}
\hline Section & $\mathrm{R}_{\mu}$ & $\mathrm{R}_{\mathrm{S}}$ & $\mathrm{R}_{\mathrm{R}}$ & $\mathrm{R}$ \\
\hline Gross & 1.77 & 2.88 & 1 & 5.10 \\
Cracked & 1.79 & 3.08 & 1 & 5.52 \\
\hline
\end{tabular}
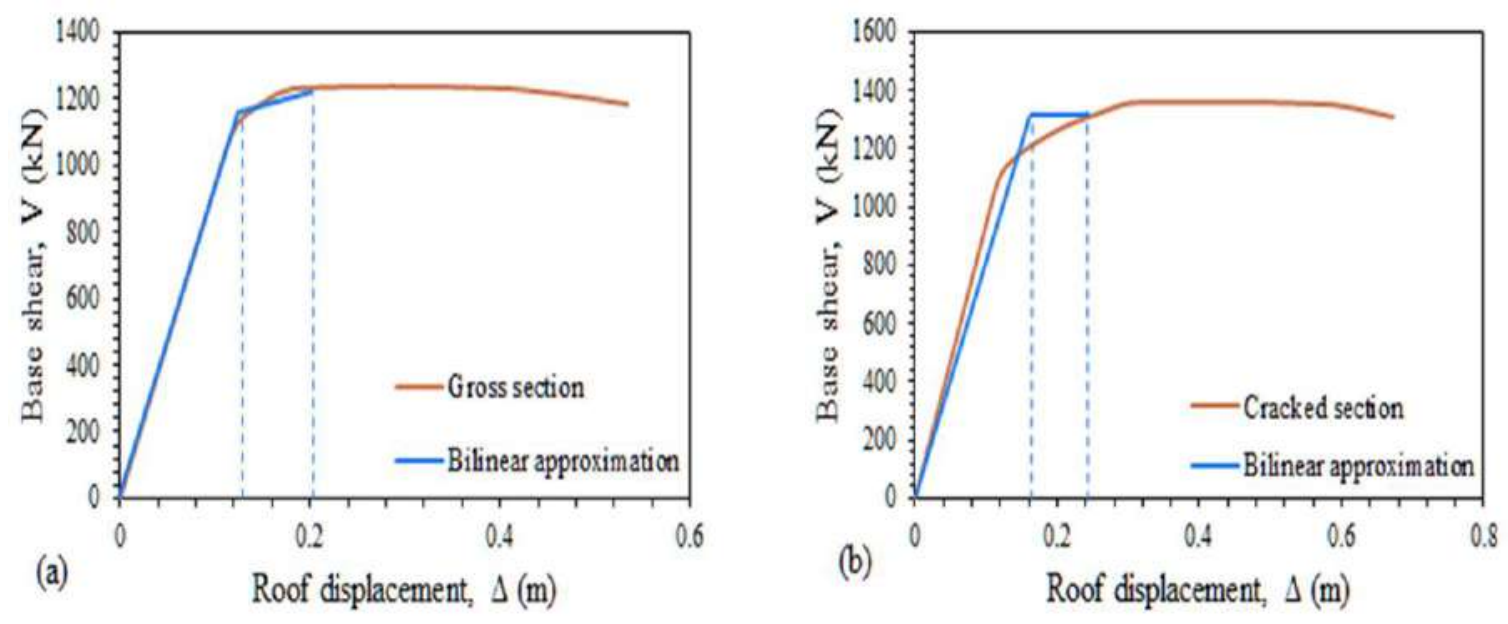

Figure 2 Pushover curve for the 12-storey RC frame building designed using (a) gross section and (b) uncracked section properties. 


\section{Seismic fragility analysis}

Fragility curves are derived using the capacity spectrum method for 12-storey RC frame buildings designed using gross and cracked section member properties. HAZUS guidelines are adopted to derive the fragility functions. The fragility curves were plotted for various damage states, namely slight, moderate, severe, and collapse, by the fragility damage function.

\section{Capacity curve}

The pushover curves are converted into ADRS format, which could be compared for the demand with the capacity curve for a 12-storey frame building. The performance point is calculated as per ATC-40 (1996) guidelines. SAP2000 software is adopted to convert the capacity curve of a pushover analysis into the ADRS format. ATC-40 contains three procedures to estimate the performance points. All three methods produce similar results. However, procedure A form ATC-40 is adopted in the current study owing to its precise and straightforward iterative method to derive the performance points. The demand and capacity curves were matched at a point considered for the displacement to occur during seismic zones III, IV and V, as shown in Table [8].

\section{Developing fragility curves}

A fragility curve is a statistical tool that helps to identify the least fragile structural design for an RC building. Further, it is vital to calculate the physical damage of a structure, risk mitigation and economic loss calculations. The fragility curve defines the probability of exceedance for expected global damage $\left(\mathrm{S}_{\mathrm{d}, \mathrm{k}}\right)$ of a building at given damage state $\left(\mathrm{S}_{\mathrm{d}}\right)$. According to the practice by HAZUS, the probability of damage state can be calculated as per the following equation (7):

$$
\rho_{\mathrm{k}}\left(\mathrm{S}_{\mathrm{d}}\right)=\mathrm{P}\left[\mathrm{DS} \geq \mathrm{DS}_{\mathrm{k}} \mid \mathrm{S}_{\mathrm{d}}\right]=\Phi\left[\frac{1}{\beta_{k}} \ln \left(\frac{S_{d}}{S_{d, k}}\right)\right]
$$

Where, $S_{d}$ is the spectral displacement; $S_{d, k}$ is the mean spectral displacement of a building in a range of the damage grade threshold; $\beta_{\mathrm{k}}$ is the standard deviation of natural logarithm for the spectral displacement of damage grades, and $\Phi$ is the standard normal cumulative distribution function.

Table 6 Performance points for the multiple demands of response spectra as per IS 1893:2016.

\begin{tabular}{llllll}
\hline Section & $\begin{array}{l}\text { Dy } \\
(\mathrm{mm})\end{array}$ & $\begin{array}{l}\text { Du } \\
(\mathrm{mm})\end{array}$ & \multicolumn{3}{l}{ Performance Points } \\
\cline { 4 - 7 } & & & $\begin{array}{l}\text { Zone V } \\
(\mathrm{mm})\end{array}$ & $\begin{array}{l}\text { Zone IV } \\
(\mathrm{mm})\end{array}$ & $\begin{array}{l}\text { Zone III } \\
(\mathrm{mm})\end{array}$ \\
\hline Gross & 90 & 450 & 325 & 165 & 113 \\
Cracked & 94 & 563 & 287 & 169 & 113 \\
\hline
\end{tabular}

\section{Uncertainty $\beta_{k}$ factor}

The spread of a fragility graph for specified damage state threshold primarily depends on the lognormal variability related to the capacity curve $(\beta \mathrm{c})$; demand spectrum $\left(\beta_{\mathrm{D}}\right)$; and discrete threshold of individually damaging state $\left(\beta_{\mathrm{T}, \mathrm{ds}}\right)$. A convolution procedure is essential to check out the overall variability ( $\left.\beta \mathrm{ds}\right)$ (HAZUS MH MR5, 2003), described as per the following equation (8): 


$$
\beta_{\mathrm{k}}=\sqrt{\left(\operatorname{CONV}\left[\beta_{C}, \beta_{D}\right]\right)^{2}+\left(\beta_{T, d s}\right)^{2}}
$$

To plot the fragility graph, an approximation of variability is a multipart mathematical process with lacking an extensive range for statistical data. The global changeability in structural damage measured is denoted by the two bases as defined above in equation (7). It is determined by merging the two variabilities with a complicated convolution procedure. The convolution process $\left(\mathrm{CONV}\left[\beta_{\mathrm{c}}, \beta_{\mathrm{D}}\right]\right)$ contains a complex mathematical calculation, which is challenging to perform due to the correlation between capacity and demand. Because of the complexity of numerical calculations and lack of wide-ranging data, uncertainty is calculated by the mean approximation of normal distribution to binomial distribution (Barbat, Pujades, \& Lantada, 2006). To estimate the value of $\beta \mathrm{k}$, it is assumed that the spectral displacement $\left(S_{d}\right)$ follows a binomial probability distribution, as mentioned in equation (9):

$$
\mathrm{P}_{\mathrm{k}}(\mathrm{N}, \mathrm{d})=\sum_{k=0}^{n-1}\left(\begin{array}{c}
n-1 \\
k
\end{array}\right) d^{k}(1-d)^{n-1-k}
$$

Where, $\mathrm{k}=0,1,2, \ldots,(\mathrm{N}-1)$; and $\mathrm{N}$ is denoted as the number of damage grades. For the current study, the value of $\mathrm{N}$ is 5 . There are two values possible for parameter $\mathrm{d} 0$ and 1 , representing the damage states of $\mathrm{RC}$ frame building. There is no damage in the $\mathrm{RC}$ frame building when the value of $\mathrm{d}$ is 0 , and there is complete damage in the $\mathrm{RC}$ frame building when the value of $\mathrm{d}$ is $1 ; \mathrm{d}=\mathrm{DS}_{\mathrm{m}} / \mathrm{N}-1$. Equation (7) was fitted to the obtained point through equation (9) by means of the least square criterion. Table [9] demonstrates the exceedance of the probability of $50 \%$ for each damage state, where the parameter $\mathrm{d}$ controls the predicted binomial probability distribution. The results exhibit the sample of a 12-storey RC frame building designed with cracked section properties. To estimate d parameters, the least square method is adopted. Table [10] shows the corresponding parameters of mean spectral displacement and uncertainty for different damage states to derive the fragility curves, i.e., (Slight, Moderate, Severe and Complete). Figure (3) illustrates the fragility curves derived for a 12storey RC frame building designed using gross and cracked section properties.

Further, the probability of exceedance $\left(\mathrm{P}_{\mathrm{k}}\right)$ is determined through the seismic hazard specification for each RC frame building designed, and the spectral displacement of a corresponding performance point (Table [8]). Thus, the probability of occurrence $\left(\mathrm{p}_{\mathrm{k}}\right)$ for each damage state is obtained from the corresponding fragility curves by subtracting the succeeding damage state exceedance probability obtained, as per the following equation (10):

$$
\mathrm{p}_{\mathrm{k}}=\mathrm{P}_{\mathrm{k}}(\mathrm{k}+1)-\mathrm{P}_{\mathrm{k}}(\mathrm{k})
$$

\section{Damage probability matrices (DPM)}

Weighted average damage index (DS $\mathrm{m}_{\mathrm{m}}$ stands nearby to the most likely damage state of RC frame building (Barbat et al. 2006), and can be derived as using equation (11) as follows:

$$
\mathrm{DS}_{\mathrm{m}}=\sum_{i=0}^{n-1} k p_{k}
$$

Where the value of $\mathrm{n}$ is chosen to be 5 for the damage grade considered in the analytical study, and the value of pk is the equivalent probability occurrence at a specific damage state. The most likely damage state is a function of the mean damage index, as shown in Table 3. The mean damage probability of a 12-storey RC frame building for the multiple hazard demand is shown in Table [11]. For instance, the calculated value of $\mathrm{DS}_{\mathrm{m}}$ is 2.1 from, as mentioned earlier (equation 11). This value indicates that the most probable damage grade of a corresponding building ranges between $1.5-2.5$, resulting in the occurrence of a moderate type of damage in the building. The $\mathrm{RC}$ frame building designed with gross and cracked section properties is analysed for the three sets of seismic 
zones. Further, the mean damage state of a 12-storey RC frame building did not exhibit the damage grade of collapse for a significant seismic hazard level.

Table 7 probabilities of the expecting damage grade while fixing a 50\% probability of each damage states.

\begin{tabular}{llllll}
\hline States & $\mathrm{d}$ & $\mathrm{DS}_{1}$ & $\mathrm{DS}_{2}$ & $\mathrm{DS}_{3}$ & $\mathrm{DS}_{4}$ \\
\hline$\rho_{1}\left(\mathrm{Sd}_{1}\right)=0.5$ & 0.22 & 0.50 & 0.30 & 0.06 & 0.01 \\
$\rho_{2}\left(\mathrm{Sd}_{2}\right)=0.5$ & 0.36 & 0.78 & 0.50 & 0.15 & 0.03 \\
$\rho_{3}\left(\mathrm{Sd}_{3}\right)=0.5$ & 0.63 & 0.99 & 0.87 & 0.50 & 0.15 \\
$\rho_{4}\left(\mathrm{Sd}_{4}\right)=0.5$ & 0.85 & 1.00 & 0.99 & 0.89 & 0.50 \\
\hline
\end{tabular}

Table 8 Parameters illustrated the fragility curve for a 12-storey $R C$ frame building.

\begin{tabular}{lllllllll}
\hline Section & $\overline{S d_{1}}$ & $\beta_{1}$ & $\overline{S d_{2}}$ & $\beta_{2}$ & $\overline{S d_{3}}$ & $\beta_{3}$ & $\overline{S d_{4}}$ & $\beta_{4}$ \\
& & & & & & & & \\
\hline Gross & 66. & 0.4 & 95. & 0.5 & 183 & 0.6 & 450 & 0.8 \\
& 8 & 2 & 4 & 7 & & 9 & & 8 \\
Cracked & 65. & 0.4 & 94. & 0.6 & 211 & 0.7 & 563 & 0.9 \\
& 2 & 7 & 0 & 9 & & 9 & & 5 \\
\hline
\end{tabular}

\section{Conclusions}

This study contributes an evaluation to the physical vulnerability of the buildings designed under the effect of seismic loads. The 12-storey RC frame building is designed with uncracked and effective section properties to get the insights into the seismic assessment of $\mathrm{R}$ factor and vulnerability. Hazards are defined as per different seismic zones (III, IV and V) suggested in Indian seismic codal provisions. 

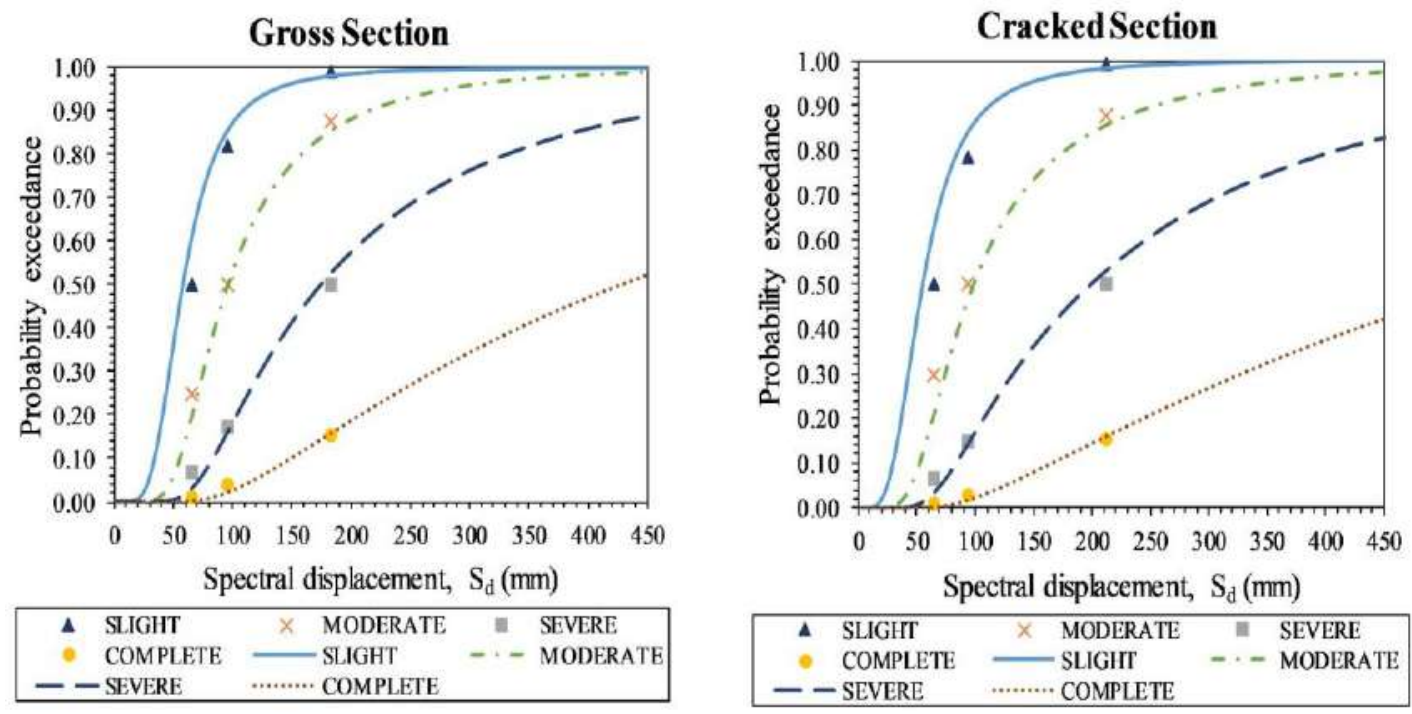

Figure 3 Fragility curve for the 12-storey RC frame building designed using uncracked and effective section properties.

Table 9 Damage probability matrices (DPM) of a 12-storey RC frame building for seismic zones (III, IV and V).

\begin{tabular}{|c|c|c|c|c|c|c|c|}
\hline \multirow[t]{2}{*}{ Section } & \multirow[t]{2}{*}{ Zone } & \multicolumn{5}{|c|}{ Damage Grade Probabilities } & \multirow[b]{2}{*}{$\mathrm{DS}_{\mathrm{m}}$} \\
\hline & & No- damage & Slight & Moderate & Severe & Complete & \\
\hline \multirow[t]{3}{*}{ Gross } & $\mathrm{V}$ & 0.002 & 0.031 & 0.171 & 0.416 & 0.379 & 3.045 \\
\hline & IV & 0.026 & 0.156 & 0.347 & 0.344 & 0.128 & 2.365 \\
\hline & III & 0.086 & 0.292 & 0.370 & 0.208 & 0.044 & 1.843 \\
\hline \multirow[t]{3}{*}{ Cracked } & $\mathrm{V}$ & 0.007 & 0.069 & 0.255 & 0.415 & 0.254 & 2.777 \\
\hline & IV & 0.034 & 0.182 & 0.361 & 0.318 & 0.105 & 2.259 \\
\hline & III & 0.100 & 0.311 & 0.364 & 0.189 & 0.037 & 1.768 \\
\hline
\end{tabular}

The uncertainty is derived using the capacity spectrum method by the approximation of normal distribution to the binomial distribution. The mean damage state of an individual building is defined to compare the seismic vulnerability of Indian seismic building design provisions as per IS 1893:2002 and IS 1893:2016. The stiffness of the infill brick masonry wall is not considered in the analysis. By performing the detailed study on the performance investigation of RC frame buildings design for gross and cracked section properties result showed the following:

- The reserve over-strength and ductility factors of an RC frame designed with effective section properties are found to be increased by $10 \%$ and $2 \%$, respectively, in comparison to an RC frame designed using uncracked section properties.

- Uncertainty value is increased from slight damage state to collapse damage state, which shows higher nonlinearity in material as it gets more damaged, providing more realistic failure prediction of structure behaviour under the seismic force.

- The RC frame designed with cracked section properties is detected to be approximately $10 \%$ less seismic vulnerable when compared to the RC frame designed using gross section properties. 
- It is observed from the values of all the probability of occurrence in damage states for various seismic zones, the $\mathrm{RC}$ frames designed with uncracked section properties could withstand more damages than the $\mathrm{RC}$ frames designed using effective section properties.

Hence, when a 12-storey RC frame building with single plan configurations and plan symmetricity was designed, the cracked section properties improve the non-linear behaviour combined with extensively decreasing the seismic vulnerability of the RC frame buildings.

\section{References}

Alam, M. S., Moni, M. and Tesfamariam, S., 2012. Seismic Overstrength and Ductility of Concrete Buildings Reinforced with Superelastic Shape Memory Alloy Rebar. Engineering Structures. Elsevier Ltd, 34, 8-20.

American Concrete Institute Committee, 2014. ACI 318-14. Building Code Requirements for Structural Concrete.

American Society of Civil Engineers, 2014. ASCE/SEI 41-13. Seismic Evaluation and Retrofit of Existing Buildings.

Applied Technology Council, 1995. ATC-19. Structural Response Modification Factors.

Applied Technology Council, 1996. ATC-40. Evaluation and Retrofit of Concrete Buildings.

Bai, J. W., Hueste, M. B. D. and Gardoni, P., 2008. Probabilistic Assessment of Structural Seismic Damage for Buildings in Mid-America. AIP Conference Proceedings, 1020(PART 1), 1685-1692.

Barbat, A. H., Pujades, L. G. and Lantada, N., 2006. Performance of Buildings under Earthquakes in Barcelona, Spain. Computer-Aided Civil and Infrastructure Engineering, 21(8), 573-593.

Barbat, A. H., Pujades, L. G. and Lantada, N., 2008. Seismic Damage Evaluation in Urban Areas using the Capacity Spectrum Method: Application to Barcelona. Soil Dynamics and Earthquake Engineering, 28(10-11), 851-865.

British Standards Institution, 2005. Eurocode 8. Design of Structures for Earthquake Resistance.

Bureau of Indian Standards, 1987. IS 875:1987. Indian Standard Code of Practice for Design Loads (Other than Earthquake) for Buildings and Structures.

Bureau of Indian Standards, 2000. IS 456:2000. Plain and Reinforced Concrete-Code of Practice.

Bureau of Indian Standards, 2002. IS 1893:2002 Criteria for Earthquake resistant design of structures, Part I: General Provisions and buildings.

Bureau of Indian Standards, 2016. IS 13920:2016. Ductile Design and Detailing of Reinforced Concrete Structures Subjected to Seismic Forces.

Bureau of Indian Standards, 2016. IS 1893:2016. Criteria for Earthquake resistant design of structures, Part I: General Provisions and buildings.

Choudhury, T., and Kaushik, H. B., 2018. Seismic Fragility of Open Ground Storey RC Frames with Wall Openings for Vulnerability Assessment. Engineering Structures, 155, 345-357.

Elnashai, A. S. and Mwafy, A. M., 2002. Overstrength and Force Reduction Factors of Multistorey ReinforcedConcrete Buildings. Structural Design of Tall Buildings, 11(5), 329-351.

Halder, L. and Paul, S., 2016. Seismic Damage Evaluation of Gravity Load Designed Low Rise RC Building Using Non-linear Static Method. Procedia Engineering. Elsevier Ltd, 1373-1380.

HAZUS-MH MR5, 2003. Advanced Engineering Building Module (AEBM): Technical and User's Manual.

M. Ahmed, M. K. D. K. and M. W., 2008. Effect of Concrete Cracking on the Lateral Response of RCC buildings. Asian Journal of Civil Engineering (Building and Housing), 9(1), 25-34.

Mapari, A. K. and Ghugal, Y. M., 2018. Seismic Performance of Multi-Storey RC SMRF and OMRF Buildings. Journal of Structural Engineering (India). Structural Engineering Research Centre, 44(6), 663-672. 
Mondal, A., Ghosh, S. and Reddy, G. R., 2013. Performance-based Evaluation of the Response Reduction Factor for Ductile RC Frames. Engineering Structures, 56, 1808-1819.

Prajapati, S. K. and Amin, J. A., 2019. Seismic Assessment of RC Frame Building Designed using Gross and Cracked Section as per Indian Standards. Asian Journal of Civil Engineering. Springer International Publishing, 20(6), 821-836.

SAP2000, C.S.I., 2020. Computers and structures Inc. Berkeley, CA, USA.

Surana, M., Singh, Y. and Lang, D. H., 2016. Seismic Performance of Concrete-Shear-Wall Buildings in India. Proceedings of the Institution of Civil Engineers: Structures and Buildings, 169(11), 809-824. 